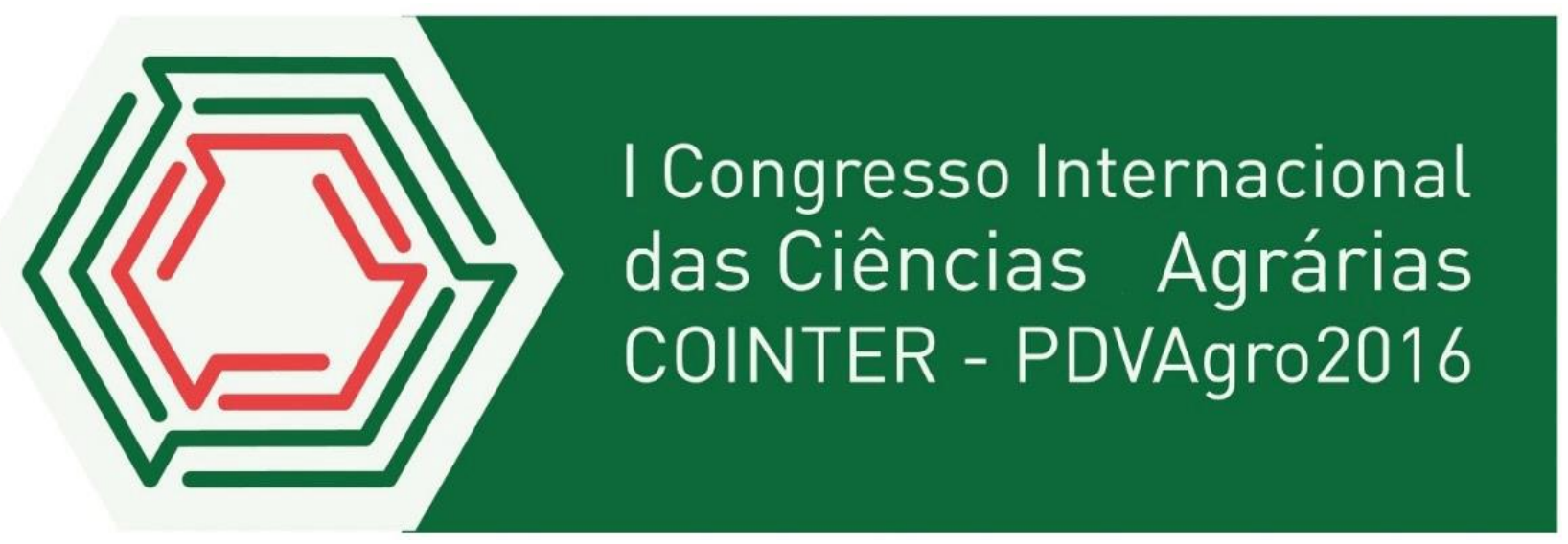

\title{
COTURNICULTURA, UMA OPÇÃO DE RENDA
}

\author{
Apresentação: Relato de Experiência \\ Bruno Wallace do Carmo Perônico우 Maciel Alves Tavares ${ }^{2}$; Rafael Gomes da Silva ${ }^{3}$; Francisca \\ Maria Silva Miranda ${ }^{4}$; Erick Viana da Silva ${ }^{5}$.
}

\section{Introdução}

A coturnicultura é a criação de codornas, sendo uma criação de alta rusticidade, pouco espaço, rápido crescimento, precocidade sexual, alta produtividade, consumo alimentar baixo, rápido retorno financeiro e com um mercado que absorve a produção, além de possibilitar dois produtos: carne e ovos (CARMO, 2007). Em relação à criação de galinhas, a codorna inicia a produção mais rápida (com 45 dias de vida), ocupa um espaço menor, pois em um local de uma galinha coloca-se até dez codornas além de poder disponibilizar gaiolas uma sobre as outras, chamada bateria (VINICIUS, 2011).

Por esses e outros motivos à coturnicultura é uma ótima opção para agricultores familiar, podendo ser um complemento na renda ou até sendo a fonte principal.

\section{Relato de Experiência}

Em julho de 2014, o autor que o escreve, teve a ideia de fazer uma pequena criação de codornas para produção de ovos, para complementação da renda familiar. A produção de ovos tem retorno mais rápido e necessita de menos espaço que a produção de codornas para abate, por isso a escolha da produção de ovos.

\footnotetext{
${ }^{1}$ Agronomia, IFPE-Vitória, brunowperonico1@gmail.com

${ }^{2}$ Agronomia, IFPE-Vitória, macieltavares15@gmail.com

${ }^{3}$ Técnico em Agroindústria, IFPE-Vitória, raffaeelsillva@hotmail.com

${ }^{4}$ Servidora, IFPE, francisca.miranda@vitoria.ifpe.edu.br

${ }^{5}$ Professor, IFPE, erick.viana@vitoria.ifpe.edu.br
} 
Nesse tempo de experiência pode-se dizer que técnicas simples aplicadas à produção renderam bons retornos dentre as quais o programa de luz, automação no sistema de bebedouros, arraçoamento correto e forma de comercialização.

O programa de luz deve ser rigoroso e somando 18 horas de luz, ou seja, além das 12 horas de luz solar, soma 6 horas de luz artificial, isso depende do período do ano. O tipo de lâmpada utilizada é a florescente, pois emite luz branca e tem maior aproveito. A luz estimula através dos olhos à glândula da hipófise que produz hormônios ligados a reprodução, assim produzindo ovos. Na produção que estamos descrevendo houve uma parada no fornecimento de luz, com isso notouse a queda da produção gradativamente em duas semanas, observando assim a necessidade desse manejo.

Quando iniciou a criação citada, o sistema de bebedouros era manual, porem essa forma de fornecimento de água estava sendo desvantajosa, isso porque logo acabava a água fornecida além de ocorrer à acumulação de sujeiras, como fezes, podendo passar enfermidades. Portanto adotou-se um sistema de bebedouros automático tipo niple com copinho, assim fornecendo água em frequência com qualidade.

A ração utilizada deve ser a comercial, pois proporciona a quantidade correta dos nutrientes, evitando que as codornas tenham queda de produção ou retirada nutrientes de seu corpo. Devendo fornecer 25 gramas para cada ave por dia, dividido essa quantidade para fornecimento em três vezes ao dia.

Com todas essas experiências e outras mais, o PDVAgro aproveitou para montagem de um minicurso, o qual foi fornecido a alunos do IFPE, tendo por intuito mostrar aos alunos não apenas a criação de codornas e experiências, mas também formas de ganhar dinheiro após finalizar o curso de técnico em agropecuária ou zootecnia, isso porque fui aluno do técnico em agropecuária no IFPE Campus Vitória, onde aprendi e apliquei as técnicas de criação.

\section{Considerações}

A coturnicultura foi e é a criação que deu experiências de criação de animais e de ser um produtor de alimento, assim como a ideia de mercado. Com isso pretende-se ampliar a criação para atender a demanda existente, iniciar a criação de codorna para abate e passar essas experiências. 


\section{Referências}

CARMO, A. K. S. (Ed.). Como iniciar sua criação de codornas de forma prática. [S.L.]. 28 ago. 2007. Disponível em: <http://www.almanaquedocampo.com.br/imagens/files/Criar\%20codornas.pdf >. Acesso em: 6 fev. 2016, 06:30:15.

VINICIUS, G. Como montar uma criação de codornas. [S.L.]. 2011. Disponível em:

<http://www.novonegocio.com.br/criacoes/como-montar-uma-criacao-de-cordornas/>. Acesso em: 6 fev. 